\title{
Evaluation of Stress Management and Stress Prevention Using Epigenetic Markers
}

\author{
Martin Stoffel $^{a} \quad$ Elena Gardini ${ }^{b, c} \quad$ Johannes C. Ehrenthal ${ }^{a} \quad$ Elvira Abbruzzese ${ }^{b}$ \\ Beate Ditzen ${ }^{a}$ \\ aInstitut für Medizinische Psychologie, Zentrum für Psychosoziale Medizin, Universitätsklinikum Heidelberg, \\ Heidelberg, Germany; ${ }^{b}$ Klinische Psychologie und Psychotherapie, Psychologisches Institut, Universität Zürich, \\ Zurich, Switzerland; ' University Research Priority Program (URPP) Dynamics of Healthy Aging, Universität Zürich, \\ Zurich, Switzerland
}

Keywords

Epigenetics · Methylation · Stress management · Stress prevention

\begin{abstract}
Stress is associated with mental health problems and physical diseases. Results from basic research indicate that stressinduced dysregulations of bodily stress response systems might mediate these processes. In consequence, many programs to prevent or manage stress have been developed and evaluated using endpoints of these bodily stress systems. Over the last few years, emerging evidence from human and animal studies has indicated that stress also leads to changes in epigenetic signatures. The functional consequences of these changes, among them altered gene expression, have been shown to modulate the psychobiological stress response. Some recent studies now show that psychosocial interventions, such as stress prevention and stress management, can alter epigenetic processes. In this review, we will present an outline on (1) relevant epigenetic mechanisms, (2) the current literature on the association of stress and epigenetics, and (3) mechanisms through which psychological interventions might alter stress-related epigenetic markers.

(c) 2020 S. Karger AG, Basel
\end{abstract}

\section{Evaluation von Stressprävention und Stressbewältigung mittels epigenetischer Marker}

\section{Schlüsselwörter}

Epigenetik · Methylierung · Stressbewältigung ·

Stressprävention

\section{Zusammenfassung}

Chronischer oder traumatischer Stress kann psychische Störungen und körperliche Erkrankungen begünstigen oder sogar verursachen. Ergebnisse aus der Grundlagenforschung zeigen, dass Stress zu einer Dysregulation wichtiger körperlicher Stresssysteme führen kann, welche diese Prozesse vermutlich vermitteln. Hierauf aufbauend wurden Interventionen zur Prävention oder zum Umgang mit Stress entwickelt, deren Wirkung mittels verschiedener Indikatoren dieser Stresssysteme evaluiert werden kann. In den letzten Jahren zeigten Ergebnisse aus Tierund Humanstudien, dass sich Stress auch auf epigenetische Signaturen auswirken kann. Die funktionellen Konsequenzen dieser Veränderungen, darunter eine veränderte Expression der betroffenen Gene, wurden zudem als Modulatoren der psychobiologischen Stressantwort beschrieben. Eine Reihe erster Pionierstudien zeigt nun, dass stressassoziierte epigenetische Prozesse durch psychologische Interventionen, darunter Stressprävention 
und Stressbewältigung, verhindert oder sogar umgekehrt werden können. In der vorliegenden Übersichtsarbeit werden (1) relevante epigenetische Mechanismen beschrieben, (2) eine Übersicht zum Zusammenhang von Epigenetik und Stress dargestellt und (3) erläutert, wie epigenetische Prozesse durch psychologische Interventionen beeinflusst werden könnten.

() 2020 S. Karger AG, Basel

\section{Stress}

Stress is one of the biggest health problems in Western societies. Research in recent years has shown that $23 \%$ of people in Germany stated that they "frequently" experience stress and 38\% said they did so "sometimes" [Techniker Krankenkasse, 2016]. A cross-sectional study in 2013, with 5,793 respondents [Hapke et al., 2013], showed that $11 \%$ of people in Germany experience chronic stress. The total sample also showed that among young people of low socioeconomic status, there is greater prevalence (17.7\%) of chronic stress. With low social support, the prevalence rises to $26.2 \%$, regardless of age. In 2018, the Bundesministerium für Arbeit und Soziales (Federal Ministry of Labor and Social Affairs), in collaboration with the Bundesanstalt für Arbeitsschutz und Arbeitsmedizin (Federal Institute for Occupational Safety and Health), published a report in which stress-related disorders were classified as the most common cause of inability to work in 2017 [Bundesministerium für Arbeit und Soziales und Bundesanstalt für Arbeitsschutz und Arbeitsmedizin, 2018]. Current estimates put the costs of stress for health systems, private individuals, and companies in the German-speaking area (Switzerland and Germany) between EUR 4.64 and 29.24 billion [Elfering et al., 2018]. The World Health Organization (WHO) determined in 2005 that the changes that people in industrialized countries are undergoing lead to stress, that this stress can cause illness, and that from the perspective of health policy, this finding should lead to the development of prevention and treatment measures [World Health Organization, 2006].

\section{The Psychobiological Stress Response}

Key to the understanding of stress is the fact that the stress response is not purely psychological, but is mediated above all by physical mechanisms. Hans Selye and Walter B. Cannon developed models that are viewed as groundbreaking to the present day, which describe how physical and psychological integrity in the face of a threatening stressor can be maintained by adjusting the level of physical activation. Selye [2013] described the physical stress response as a three-phased "general adaptation syndrome": (1) In the alarm reaction, the body is in a kind of shock state, as a result of which physical activation is initially reduced. Physical activation is then greatly increased in the anti-shock reaction. The "fight-or-flight" reaction described by Cannon can also be classified within the framework of the anti-shock stage [Cannon, 1915]. By activating the sympathetic nervous system, important target systems for the "fight-or-flight" reaction are activated, especially by adrenergic innervation (e.g., respiration, blood flow, muscle tension). The other phases of the model explain mainly (2) adaptation to longer-lasting stressors (resistance phase) and (3) the overloading of the individual when exposure is too long (exhaustion phase).

In early theories of stress, the stressors were often physical, such as extreme cold or sudden pain stimuli, which immediately trigger a physical stress response. The great importance of psychological factors for the activation of physical stress systems was only further elucidated and finally acknowledged in later work. This led, for example, to the term "psychoendocrine," which refers to activation of the hormonal stress response by psychological stimuli [e.g., Mason, 1971]. Since then, some physical systems have become known that are activated by psychological stress. Two characteristic physical stress axes have been most frequently studied and described [Gunnar and Quevedo, 2007]: The first of these concerns activation of the sympathetic nervous system to provide resources (e.g., increased cardiac output) during the "fightor-flight" reaction (sympatho-adrenomedullary system). The activity of the second stress axis, the hypothalamicpituitary-adrenocortical (HPA) axis, cannot be measured until several minutes after the stressor has appeared. Its end product, cortisol, encounters receptors in the target cells and triggers a cascade of intracellular processes, ultimately to provide resources (e.g., glucose) and maintain mental and physical functioning [Sapolsky et al., 2000]. The effects of stress on the body, however, are even more diverse and affect many other bodily systems. For example, acute stress leads to upregulation of nonspecific immunity, whereas chronic stress is associated with a reduction in the humoral and cellular immune response [Segerstrom and Miller, 2004]. Chronic stress also affects the structural plasticity in some brain regions (e.g., atrophy of the dendrites and a reduced number of synapses) that are highly relevant for regulation of the stress response [Hunter et al., 2015].

Detailed analysis of the stress response showed that it is regulated by central nervous emotional and cognitive mechanisms (neurobiologically, e.g., by activation of the amygdala). These findings are summarized in the "allostasis stress model" [cf. McEwen and Wingfield, 2003], which describes the cognitive evaluation of the threat that situations pose as crucial for the emergence of psychobio- 
logical stress. The model also integrates (1) the influences of interindividual dispositions (such as genetic factors or early childhood experiences) on situation assessment and physical stress response, and (2) the important function of behavior as a moderator between situation assessment and the stress response. "Allostasis" can be translated as "stability through change," i.e., the psychobiological processes that can lead to adaptation to stressors in both the short and long term. So-called "allostatic stress" is particularly important for clinical psychology. It describes the wear and tear that occurs when a permanent and thus resource-intensive adaptation to stressors becomes necessary. The result can be, for example, a dysregulation of the hormonal stress response or a disturbed regulation of the immune system. This changed allostasis - i.e., the long-term adaptation to one or more stressors - is moderated by a number of biological mechanisms. These mechanisms, on the one hand, are activated by psychological stress and, on the other hand, are the endpoints of the physical stress systems described [Juster et al., 2010]. Such endpoints can be measured, for example, via peripheral physiological methods (e.g., by an electrocardiogram) or by biochemical assays (e.g., cortisol in saliva or immune parameters in blood); these endpoints can be used in studies to evaluate psychological interventions [Juster et al., 2010].

\section{Genetic and Epigenetic Factors in Stress Processing}

Genetic variations (so-called polymorphisms) of candidate genes, which are involved in the regulation of physical stress systems, have been intensively studied in the last few decades in connection with stress and psychopathology. The initial studies reported such relationships for the serotonin transporter gene (SLC6A4) [see for example Karg et al., 2011], the gene that encodes the FK506binding protein 51 (FKBP5) [see for example Zannas et al., 2016], and the glucocorticoid receptor gene (NR3C1) [see for example Lian et al., 2014]. The cited works describe so-called "gene-environment interactions." The objective of these studies is to determine whether genetic dispositions have an impact on how vulnerable an individual is to developing a mental disorder when confronting stress-inducing environmental influences. Despite the initially promising results, a recent review of large samples refutes the assumption that genetic variations in candidate genes could affect vulnerability to depressive disorders [Border et al., 2019]. In the same work, no evidence was reported of direct associations of candidate genes with depressive disorders [Border et al., 2019]. Other genome-wide studies with large numbers of cases confirm the lack of main effects of candidate gene polymor- phisms [Wray et al., 2018; Howard et al., 2019] and report only small effect sizes for the direct association of 102 independent genetic variations [Howard et al., 2019] and 44 gene loci [Wray et al., 2018] with depressive disorders. Results for candidate gene-environment interactions are often also not replicable for other mental disorders, such as schizophrenia [Assary et al., 2018]. This could be because candidate gene studies have overlooked the polygenic character of mental disorders, i.e., the interaction of several genes [Assary et al., 2018]. In summary, explaining the complexity of the genesis of stress-related mental disorders by genetic variations has been only partially successful.

However, the importance of environmental factors in the emergence of mental disorders is undisputed [Border et al., 2019]. It has only been known for a few years that stressors may include environmental factors that mediate a change in gene activity in important target systems [see for example Zannas and West, 2014]. The processes through which such an influence is mediated are attributed to the field of "epigenetics." This specialty deals with molecular biological processes which, irrespective of the DNA sequence, can affect whether a gene is activated [Wu and Morris, 2001]. The epigenetic states resulting from these processes are inherited in the process of cell division, but are potentially reversible [Schuebel et al., 2016]. The most important and most frequently studied epigenetic mechanisms in connection with stress will be briefly discussed below.

\section{Structure of the DNA}

The DNA strand in the cell nucleus is not unstructured. Short sections of the strand are each wrapped around complexes of eight histone proteins [Portela and Esteller, 2010]. The resulting complexes are called nucleosomes [Portela and Esteller, 2010]. Certain epigenetic modifications, mainly at the unstructured ends of these proteins (so-called "histone tails"), can potentially alter the activation of genes. A combination and interaction of several of these epigenetic changes results in the DNA being wrapped more or less tightly around the histones. Such mechanisms include, for example, phosphorylation, methylation, and acetylation, and their respective counterparts (such as deacetylation by histone deacetylases) [Schroeder et al., 2012]. A stronger compression of the complex leads to "heterochromatin," while an unfolding leads to "euchromatin." In the unfolded and less tightly wrapped state, better access of certain proteins (so-called "transcription factors") is possible; these are important for initiation of gene expression (so-called "transcription"). This leads to better activation of the relevant gene [Schroeder et al., 2012]. In addition to these so-called "histone modifications," it is important how the connections from the DNA strand and proteins - the nucleo- 
somes - are arranged in the cell nucleus. This applies particularly to the transcription start site, since a complex of enzymes (RNA polymerase) binds there, reads the genetic material, and thus initiates the synthesis of new proteins. There are diverse epigenetic processes that influence the arrangement of the nucleosomes. ATP-dependent enzyme complexes ("chromatin remodeling complexes"), which can reposition, destabilize, or reject nucleosomes, are particularly important [Ho and Crabtree, 2010].

\section{DNA Methylation}

DNA methylation has been studied far more often than epigenetic processes that directly affect the structure of DNA, especially in psychiatric research, which is why this review will mainly deal with the former process. DNA methylation is a process by which certain enzymes (socalled methyl groups) are attached to the building blocks of DNA (e.g. the cytosine of cytosine-phosphate-guanine dinucleotides [CpG dinucleotides], as well as $\mathrm{CpA}, \mathrm{CpC}$, or CpT dinucleotides) [Portela and Esteller, 2010]. The methylated cytosine becomes 5-methylcytosine and, especially in areas in which $\mathrm{CpG}$ dinucleotides are abundant ("CpG islands"), can result in reduced gene activation, the so-called "silencing" effect [Jones, 2012]. This effect can take place because a higher CpG methylation, especially when it takes place at the transcription start site, can inhibit transcription factor binding and thus transcription initiation [Jones, 2012]. It has also been shown that methylation in the gene body - i.e., not in the transcription start site - can be relevant for transcription [Varley et al., 2013]. Methylation of CpG dinucleotides also leads to the recruitment of certain protein complexes that can cause structural changes in the DNA (histone modifications and changes in the chromatin structure) [Bogdanović and Veenstra, 2009]. This again leads to changed activation of the genes, in accordance with the functions of the epigenetic processes described above.

\section{Epigenetics and Stress}

About 15 years ago, an initial study [Weaver et al., 2004] provided evidence that physical systems and regulatory mechanisms that are involved in the psychobiological stress response can also be influenced by epigenetic processes. The authors were able to demonstrate that in rats, reduced maternal care changed the methylation of NR3C1 in the offspring, resulted in altered transcription factor binding (NGFI-A), influenced histone acetylation, and, presumably as a consequence of these processes, led to altered $\mathrm{Nr} 3 \mathrm{cl}$ expression. The authors thereby demonstrated that maternal care affected HPA axis reactivity to acute stress in the offspring. This study was groundbreak- ing in the emergence of a new field of research, "behavioral epigenetics," which associated behavioral patterns with changes in the epigenetic signature of relevant candidate genes [Lester et al., 2011]. Since then, numerous studies, including with humans, have shown that a change in exposure to environmental influences can affect epigenetic processes. Several reviews have shown the effects of stress on epigenetic processes in genes that are relevant for mental health. This includes stress experienced prenatally [Provenzi et al., 2018], in early childhood [Jiang et al., 2019], and in early phases of life [Vaiserman, 2015]. Many publications in the field of behavioral epigenetics focus on prenatal or early childhood influences, because there is particularly high vulnerability and plasticity in these developmental phases [Pérez et al., 2019]. The findings about these influences can be regarded as robustly replicated due to the large number of findings.

It has been known for some years, however, that epigenetic processes can still be changed in adulthood [Sweatt, 2009], since the enzymes necessary for methylation (methyltransferases) are still active in the adult brain [Feng et al., 2010]; this has also been proven in studies on humans [e.g., Siegmund et al., 2007]. With regard to stress, several findings show that especially prolonged phases of stress exposure (for example, work-related or traumatic conditions, or those based on socioeconomic conditions or chronic stress) can change the methylation of a variety of candidate genes in adulthood [Unternaehrer and Meinlschmidt, 2016; Bakusic et al., 2017; Park et al., 2019]. Some earlier studies also suggest that active methyltransferases are specifically involved in the control of neuronal and behavioral adaptations in adulthood, including memory processes [Heyward and Sweatt, 2015], cognitive abilities that decrease with age [Oliveira et al., 2012], and depressive behavior [LaPlant et al., 2010]. In two studies of rats, the first evidence was found that even acute stress could have a specific impact on the methylation of certain candidate genes [Miller and Sweatt, 2007] as well as on global DNA methylation [Rodrigues et al., 2015]. A recent study of adult rats also yielded evidence that an enzyme for methylation after exposure to acute stress was increasingly associated with $\mathrm{Nr} 3 c 1$, which resulted in active methylation and reduced activation of the gene [Mifsud et al., 2017]. It has also been shown twice so far that chronic stress leads to a change in the activation of enzymes that control the methylation of, among other things, stress-relevant genes [Elliott et al., 2010; LaPlant et al., 2010]. Interestingly, the results of an initial study of humans also suggest that acute psychosocial stress could be associated with increased methylation of the oxytocin receptor gene $(O X T R)$ [Unternaehrer et al., 2012]. Since the methylation of OXTR itself is functionally associated with HPA axis reactivity to acute psychosocial stress [Ziegler et al., 2015], it can also be assumed that epigen- 
etic processes in this case mediated rapid adaptation to acute stress. In sum, these findings suggest that methylation is still possible in mature cells and is probably a decisive factor for the plasticity and adaptability of the adult brain [Bayraktar and Kreutz, 2018]. A number of candidate genes are mentioned especially often in the works cited above. Among these are NR3C1 [see Turecki and Meaney, 2016, for a review], SLC6A4 [see Palma-Gudiel and Fañanás, 2017, for a review], as well FKBP5 [see Zannas et al., 2016, for a review]. We infer from the cited reviews that epigenetic processes in all three genes participate in regulation of the HPA axis. They also covary with functional processes and/or structural changes in brain regions that are key to control of the physical stress response [Nikolova and Hariri, 2015].

\section{Reversibility of Stress-Related Epigenetic Signatures}

The results of the study by Weaver and colleagues [2004] also support the assumption that epigenetic mechanisms do not just occur prenatally or in early childhood, but continue in the adult brain (see Chapter 4). The authors were able to demonstrate that the epigenetic processes in $\mathrm{Nr} 3 \mathrm{cl}$ that were induced by a lack of maternal behavior could be overridden by the administration of a histone deacetylase inhibitor. This "proof of concept" demonstration of the reversibility of behaviorally determined epigenetic stress-related signatures is key to the assumption of a highly dynamic epigenome that could respond not only to stress, but also to management of stress or promotion of resilience [Zannas and Binder, 2014].

These findings are directly relevant to the evaluation of psychotherapeutic interventions, and the first longitudinal studies have been done in which epigenetic signatures of candidate genes in people with mental disorders were examined before and after psychotherapeutic interventions. These studies report a covariation of symptom improvement and changes in the epigenetic signature of $B D N F$ (a gene encoding a growth factor) [Perroud et al., 2013], FKBP5 [Yehuda et al., 2013; Roberts et al., 2015, 2019], and SLC6A4 [Roberts et al., 2014]. Although there are only a few studies on the reversibility of stress-related epigenetic signatures so far, measurement of these particular signatures seems promising, especially to evaluate the effectiveness of stress prevention and stress management. Increasing resilience by means of health-promoting cognitive and behavioral patterns under stress could thus be mediated by redirecting maladaptive epigenetic signatures [McEwen, 2016]. In the long term, it may therefore be possible to use interventions to promote resilience or to cope with stress specifically for this purpose, and to interpret the change in the epigenetic signature as a measure of their effectiveness [Szyf et al., 2016].

\section{Stress Prevention and Stress Management}

Quite a few interventions have been developed to prevent or manage stress. Many of these interventions have been found to be effective, including relaxation procedures [Esch et al., 2003], psychoeducation [Van Daele et al., 2012], and cognitive-behavioral procedures [Varvogli and Darviri, 2011]. Overarching factors are also known that can reduce or prevent stress, such as social support [Ditzen and Heinrichs, 2014], sports, and adequate and regular sleep. Mindfulness-based interventions are particularly noteworthy; they are not only by far the best studied, but they also present the most robust evidence of health-promoting effects [Gu et al., 2015], such as changes in the activation of various brain areas involved in the stress response [Tang et al., 2015].

The first works have just been published in the last few years that suggest that the health-promoting effects of mindfulness practice could be in part epigenetically mediated. In a recent study, epigenome-wide methylation was examined in a total of 34 people, 17 of whom had at least 10 years of meditation experience [García-Campayo et al., 2018]. The findings showed 64 differentially methylated regions on a total of 43 genes, about half of which are associated with physical illnesses and mental disorders.

In an earlier study, the effects of a 1-day mindfulnessbased intervention were examined in a group of 19 participants with meditation experience ( $>3$ years of experience). The control group was made up of 21 participants inexperienced in meditation, who engaged in leisure activities during the intervention period. All parameters were collected for both groups, once before and once after the intervention (or leisure activities). Compared to the control group, the intervention group over time showed a reduced expression of histone deacetylase genes (HDAC2, HDAC3, HDAC9) and pro-inflammatory genes (RIPK2 and COX-2), as well as global modifications of histones (H4ac and H3K4me3) [Kaliman et al., 2014]. The authors further report that the expression of RIPK2 and HDAC2 in the total sample was associated with reduced HPA axis reactivity to acute psychosocial stress. In an epigenome-wide analysis of the same sample, the authors also found significant changes over time only in the intervention group in methylation of $61 \mathrm{CpG}$ dinucleotides [Chaix et al., 2019]. The 61 dinucleotides were described as frequently located in $\mathrm{CpG}$ islands and assigned to genes that have functions in the control of the immune system and aging. In a cross-sectional analysis of the same 
sample, the authors were also able to demonstrate that the age-related acceleration of epigenetic aging processes ("epigenetic clock") after the age of 52 was not as pronounced in 17 of the meditation-experienced subjects as in the control group of subjects not experienced in meditation [Chaix et al., 2017]. The concept of the "epigenetic clock" described in the study means that, based on the methylation of $353 \mathrm{CpG}$ dinucleotides, an epigenetic age can be determined that predicts a variety of health parameters [Horvath, 2013].

A recent study of 22 traumatized war veterans focused on a standardized mindfulness-based stress reduction (MBSR) program [Bishop et al., 2018]. The authors report that in 11 veterans, alongside the reduction in trauma symptoms through the MBSR intervention, there was also a reduction in FKBP5 methylation. The authors report no such effect, however, for the methylation of SLC6A4, which was also examined in the study. Although more and larger studies are needed to make a definitive statement about the individual epigenetic changes, the evidence to date is highly interesting that mindfulnessbased procedures have a measurable effect on epigenetic processes [see Kaliman, 2019].

In a separate study on a sample of medical students, with a focus on epigenetic processes in SLC6A4, we recently showed that methylation can be influenced by a 3-month mindfulness-based intervention [see Stoffel et al., 2019a, for details]. In this study, methylation was examined at $56 \mathrm{CpG}$ dinucleotides located in an area in which epigenetic processes are important for activation of the gene (a so-called "promoter-associated" region). The mean methylation decreased in the intervention group over the 3 months and remained almost unchanged in a control group. Since lower methylation in precisely the area that we examined in the study is demonstrably associated with lower stress [Palma-Gudiel and Fañanás, 2017], it may be concluded that these changes have a stress-protective effect. This assumption is supported above all by the fact that a greater decrease in methylation was associated with a greater reduction in the subjective stress experience and the self-assessment that one is generally better at dealing with stress. In addition, the reduction in methylation was greater in the subjects who had performed stress management exercises outside of the intervention sessions, in their everyday life. Finally, the results showed that a reduction in methylation could actually be functionally relevant to serotonin metabolism, since a decrease in methylation was associated with an increase in the expression of $S L C 6 A 4$, suggesting a stronger activation of the gene. According to these findings, the SLC6A4 expression increased significantly more over the 3 -month period in the intervention group than in the control group. It is also interesting that frequently examined structural ge- netic variations in SLC6A4 showed no effect on the results described.

In another study, we examined a stress management intervention that, among other things, uses techniques of solution-oriented short-term therapy in dealing with stressors [De Shazer and Dolan, 2016] and explicitly promotes the use of social contacts as resources. The intervention entitled "Der Grüne Bereich" (The Green Area) [Ditzen and Ehlert, 2014] was carried out in several groups of workers on 2 days, 1 week apart. Before and after the intervention, the methylation of FKBP5 and $N R 3 C 1$, as well as the release of cortisol in everyday life, were recorded once per subject. Initial results suggest that the methylation of FKBP5 increased significantly in the intervention group within the week between the two measurements, while it did not change in the control group [Stoffel et al., 2017]. Furthermore, the methylation at two of the five CpG dinucleotides of FKBP5 was significantly associated with the circadian rhythm of cortisol [Stoffel et al., 2019b]. Taken together, it appears that epigenetic processes - especially in important candidate genes such as FKBP5 or SLC6A4 - are not only highly reactive to stress, but can probably also be affected by preventing or coping with stress. Because of the important functions that these genes play in the stress response, they could therefore be very suitable for evaluating interventions that address the stress systems. Future studies will have to show whether the initial evidence presented in this review can be robustly replicated.

\section{Limits of Evaluation of Stress Management and Stress Prevention Using Epigenetic Markers}

The field of research dealing with evaluation of psychological interventions using epigenetic markers is still very heterogeneous. This applies, for example, to the genes studied, the biochemical methods used [see Kurdyukov and Bullock, 2016, for a review], the data processing, the populations and stress-related disorders studied, as well as the interventions investigated. This heterogeneity makes it difficult to generalize the findings to date.

In Chapters 3 to 6 above, the three genes SLC6A4, FKBP5, and NR3C1 were given as examples, which, since they have already been studied many times in connection with stress, serve as candidate genes for stress research [see Bakusic et al., 2017; Park et al., 2019, for a review and additional candidate genes]. Nevertheless, the candidate gene approach, which has hitherto been used in most studies, presents methodological difficulties: For example, it has been shown that there is a high degree of covariation of the methylation between subunits of CpG dinucleotides across the entire genome. This covariation can only be adequately controlled in epigenome-wide analyses, since
Verhaltenstherapie

DOI: $10.1159 / 000506323$
Stoffel/Gardini/Ehrenthal/Abbruzzese/ Ditzen 
only a few $\mathrm{CpG}$ dinucleotides are analyzed in candidate gene studies (compared to up to around 850,000 in epigenome-wide analyses) [Shabalin et al., 2015]. The alternative use of epigenome-wide analyses is also conceivable in a longitudinal intervention design, but would present specific challenges [Michels et al., 2013], including above all the need for very large samples, the currently still high costs, and the potentially low coverage of CpG dinucleotides on relevant genes by the array used.

A further limitation is due to the fact that the tissue of the target organ relevant to the research of psychological processes, the brain, is only accessible postmortem. Therefore, tissues mostly available in the periphery of the body have to be used for epigenetic analyses; peripheral blood, saliva samples, or cells from the oral mucosa are often used for this purpose. However, since methylation can be cell- and tissue-specific, the choice of tissue for extracting the genomic DNA can influence the results of the study [Zhang et al., 2013]. In order to determine to what extent methylation in the brain is associated with methylation of tissue in the periphery, online tools accessing different databases were developed, with which a direct comparison is possible [e.g., Braun et al., 2019]. Statistical methods could be used, for example, to observe the influence of cell composition on methylation data [e.g., Jones et al., 2017].

\section{Conclusion and Outlook}

In agreement with an earlier review, which dealt with the role of epigenetic processes in the field of health promotion in general [McBride and Koehly, 2017], the following can be stated: (1) Epigenetic factors are actively and flexibly altered by environmental influences. Measuring these changes has great potential to function as a biomarker in the future. Epigenetic signatures on candidate genes in which an association with one of the target constructs - stress or resilience - has been stably proven, particularly lend themselves to this. Systematic studies of the sensitivity and specificity of epigenetic markers for prediction of the target constructs will have to show in the future whether the criteria for using epigenetic signatures as biomarkers can be met formally. (2) As targeted environmental influences, interventions to promote health could also modify epigenetic patterns: If there is sufficient evidence for the covariation of a certain epigenetic signature with one of the target constructs, changes in this particular signature could in the future be used as an objective indicator of the success of the interventions under study. Specifically with regard to stress, the studies presented in the present review give the first indications that stress-dependent changes in epigenetic signatures could actually be buffered through stress prevention or coping interventions, including notably mindfulness-based interventions. In order to further understand the relationship between stress and epigenetic changes, however, it would be highly interesting to conduct additional epigenome-wide association studies [see Rakyan et al., 2011]. Candidate genes do often fulfill important functions in systems that regulate the psychobiological stress response, but they do not cover all the health parameters that are altered by stress. It would also then be possible to examine epigenetic profiles - for the purpose of personalized care - as predictors of the success of the intervention.

Over the long term, the development we have described could make it possible to objectify the successes of psychotherapy - beyond self-reporting and behavioral observation - on an epigenetic level. Finally, the results of the initial studies presented in this review suggest that psychological interventions might influence the regulation of stress-related epigenetic processes. Future randomized controlled intervention studies will have to show whether this assumption is valid.

\section{Acknowledgements}

The work was financially supported by the Ministry of Science, Research and the Arts of Baden-Württemberg. The sponsoring organization had no influence on the development of the work.

\section{Disclosure Statement}

There are no conflicts of interest in connection with the review. The review is based on parts of the dissertation "Psychobiologische Evaluation eines Stressbewältigungstrainings im Alltag" by Martin Stoffel, which was submitted in September 2019 to the Heidelberg Medical Faculty of the University of Heidelberg in fulfilment of the requirements for the degree of Doctor scientiarum humanarum (Dr. sc. hum.).

References

Assary E, Vincent JP, Keers R, Pluess M. Geneenvironment interaction and psychiatric disorders: review and future directions. Semin Cell Dev Biol. 2018 May;77:133-43.

Bakusic J, Schaufeli W, Claes S, Godderis L. Stress, burnout and depression: A systematic review on DNA methylation mechanisms. J Psychosom Res. 2017 Jan;92:34-44.

Bayraktar G, Kreutz MR. Neuronal DNA Methyltransferases: Epigenetic Mediators between Synaptic Activity and Gene Expression? Neuroscientist. 2018 Apr;24(2):171-85.

Bishop JR, Lee AM, Mills LJ, Thuras PD, Eum S, Clancy D, et al. Methylation of FKBP5 and SLC6A4 in Relation to Treatment Response to Mindfulness Based Stress Reduction for Posttraumatic Stress Disorder. Front Psychiatry. 2018 Sep;9:418.

Bogdanović O, Veenstra GJ. DNA methylation and methyl-CpG binding proteins: developmental requirements and function. Chromosoma. 2009 Oct;118(5):549-65. 
Border R, Johnson EC, Evans LM, Smolen A, Berley N, Sullivan PF, et al. No Support for Historical Candidate Gene or Candidate Geneby-Interaction Hypotheses for Major Depression Across Multiple Large Samples. Am J Psychiatry. 2019 May;176(5):376-87.

Braun PR, Han S, Hing B, Nagahama Y, Gaul LN, Heinzman JT, et al. Genome-wide DNA methylation comparison between live human brain and peripheral tissues within individuals. Transl Psychiatry. 2019 Jan;9(1):47.

Bundesministerium für Arbeit und Soziales, Bundesanstalt für Arbeitsschutz und Arbeitsmedizin: Sicherheit und Gesundheit bei der Arbeit - Berichtsjahr 2017. Unfallverhütungsbericht Arbeit. Dortmund, Kettler, 2018. https://www.baua.de/DE/Angebote/ Publikationen/Berichte/Suga-2017. pdf\%3F__blob\%3DpublicationFile $\% 26 \mathrm{v} \%$ 3D13

Cannon WB. Bodily changes in pain, hunger, fear and rage: An account of recent researches into the function of emotional excitement. New York: D. Appleton \& Company; 1915. https:// doi.org/10.1037/10013-000.

Chaix R, Alvarez-López MJ, Fagny M, Lemee L, Regnault B, Davidson RJ, et al. Epigenetic clock analysis in long-term meditators. Psychoneuroendocrinology. 2017 Nov;85:210-4.

Chaix R, Fagny M, Cosin-Tomás M, AlvarezLópez M, Lemee L, Regnault B, et al. Differential DNA methylation in experienced meditators after an intensive day of mindfulnessbased practice: implications for immunerelated pathways. Brain Behav Immun. 2019 Nov 13. pii: S0889-1591(19)30879-7.

De Shazer S, Dolan Y. Mehr als ein Wunder: Die Kunst der lösungsorientierten Kurzzeittherapie. Heidelberg: Carl-Auer Verlag $\mathrm{GmbH}$; 2016.

Ditzen B, Ehlert U. Stress und stressabhängige körperliche Störungen. In: Vaitl D, Petermann F, editors. Entspannungsverfahren. Das Praxishandbuch. Weinheim: Beltz; 2014. pp. 175-89.

Ditzen B, Heinrichs M. Psychobiology of social support: the social dimension of stress buffering. Restor Neurol Neurosci. 2014;32(1):14962.

Elfering A, Brunner B, Igic I, et al. Gesellschaftliche Bedeutung und Kosten von Stress. In: Fuchs R, Gerber M, editors. Handbuch Stressregulation und Sport. Berlin, Heidelberg: Springer Berlin Heidelberg; 2018. pp. 123-41.

Elliott E, Ezra-Nevo G, Regev L, Neufeld-Cohen A, Chen A. Resilience to social stress coincides with functional DNA methylation of the Crf gene in adult mice. Nat Neurosci. 2010 Nov;13(11):1351-3.

Esch T, Fricchione GL, Stefano GB. The therapeutic use of the relaxation response in stress-related diseases. Med Sci Monit. 2003 Feb; 9(2):RA23-34.

Feng J, Zhou Y, Campbell SL, Le T, Li E, Sweatt JD, et al. Dnmt1 and Dnmt3a maintain DNA methylation and regulate synaptic function in adult forebrain neurons. Nat Neurosci. 2010 Apr;13(4):423-30.

García-Campayo J, Puebla-Guedea M, Labarga A Urdánoz A, Roldán M, Pulido L, et al. Epigenetic Response to Mindfulness in Periphera Blood Leukocytes Involves Genes Linked to
Common Human Diseases. Mindfulness (N Y). 2018;9(4):1146-59.

Gu J, Strauss C, Bond R, Cavanagh K. How do mindfulness-based cognitive therapy and mindfulness-based stress reduction improve mental health and wellbeing? A systematic review and meta-analysis of mediation studies. Clin Psychol Rev. 2015 Apr;37:1-12.

Gunnar M, Quevedo K. The neurobiology of stress and development. Annu Rev Psychol. 2007;58(1):145-73.

Hapke U, Maske UE, Scheidt-Nave C, Bode L, Schlack R, Busch MA. Chronischer Stress bei Erwachsenen in Deutschland: Ergebnisse der Studie zur Gesundheit Erwachsener in Deutschland (DEGS1). Bundesgesundheitsblatt Gesundheitsforschung Gesundheitsschutz. 2013 May;56(5-6):749-54

Heyward FD, Sweatt JD. DNA Methylation in Memory Formation: emerging Insights. Neuroscientist. 2015 Oct;21(5):475-89.

Ho L, Crabtree GR. Chromatin remodelling during development. Nature. 2010 Jan;463(7280): 474-84.

Horvath S. DNA methylation age of human tissues and cell types. Genome Biol. 2013; 14(10):R115

Howard DM, Adams MJ, Clarke TK, Hafferty JD, Gibson J, Shirali M, et al.; 23andMe Research Team; Major Depressive Disorder Working Group of the Psychiatric Genomics Consortium. Genome-wide meta-analysis of depression identifies 102 independent variants and highlights the importance of the prefrontal brain regions. Nat Neurosci. 2019 Mar;22(3): 343-52.

Hunter RG, Gagnidze K, McEwen BS, Pfaff DW. Stress and the dynamic genome: Steroids, epigenetics, and the transposome. Proc Natl Acad Sci USA. 2015 Jun;112(22):6828-33

Jiang S, Postovit L, Cattaneo A, Binder EB, Aitchison KJ. Epigenetic Modifications in Stress Response Genes Associated With Childhood Trauma. Front Psychiatry. 2019 Nov; 10:808.

Jones MJ, Islam SA, Edgar RD, Kobor MS. Adjusting for Cell Type Composition in DNA Methylation Data Using a Regression-Based Approach. Methods Mol Biol. 2017;1589:99106

Jones PA. Functions of DNA methylation: islands, start sites, gene bodies and beyond. Nat Rev Genet. 2012 May;13(7):484-92.

Juster RP, McEwen BS, Lupien SJ. Allostatic load biomarkers of chronic stress and impact on health and cognition. Neurosci Biobehav Rev. 2010 Sep;35(1):2-16.

Kaliman P, Alvarez-López MJ, Cosín-Tomás M, Rosenkranz MA, Lutz A, Davidson RJ. Rapid changes in histone deacetylases and inflammatory gene expression in expert meditators. Psychoneuroendocrinology. 2014 Feb;40:96-107.

Kaliman P. Epigenetics and meditation. Curr Opin Psychol. 2019 Aug;28:76-80.

Karg K, Burmeister M, Shedden K, Sen S. The serotonin transporter promoter variant (5-HTTLPR), stress, and depression meta-analysis revisited: evidence of genetic moderation. Arch Gen Psychiatry. 2011 May;68(5):44454.

Kurdyukov S, Bullock M. DNA Methylation Analysis: Choosing the Right Method. Biology (Basel). 2016 Jan;5(1):E3.
LaPlant Q, Vialou V, Covington HE 3rd, Dumitriu D, Feng J, Warren BL, et al. Dnmt3a regulates emotional behavior and spine plasticity in the nucleus accumbens. Nat Neurosci. 2010 Sep;13(9):1137-43.

Lester BM, Tronick E, Nestler E, Abel T, Kosofsky B, Kuzawa CW, et al. Behavioral epigenetics. Ann N Y Acad Sci. 2011 May;1226(1):14-33.

Lian Y, Xiao J, Wang Q, Ning L, Guan S, Ge H, et al. The relationship between glucocorticoid receptor polymorphisms, stressful life events, social support, and post-traumatic stress disorder. BMC Psychiatry. 2014 Aug;14(1):232.

Mason JW. A re-evaluation of the concept of "non-specificity" in stress theory. J Psychiatr Res. 1971 Aug;8(3):323-33.

McBride CM, Koehly LM. Imagining roles for epigenetics in health promotion research. J Behav Med. 2017 Apr;40(2):229-38.

McEwen BS, Wingfield JC. The concept of allostasis in biology and biomedicine. Horm Behav. 2003 Jan;43(1):2-15.

McEwen BS. In pursuit of resilience: stress, epigenetics, and brain plasticity. Ann N Y Acad Sci. 2016 Jun;1373(1):56-64.

Michels KB, Binder AM, Dedeurwaerder S, Epstein CB, Greally JM, Gut I, et al. Recommendations for the design and analysis of epigenome-wide association studies. Nat Methods. 2013 Oct;10(10):949-55.

Mifsud KR, Saunderson EA, Spiers H, Carter SD, Trollope AF, Mill J, et al. Rapid Down-Regulation of Glucocorticoid Receptor Gene Expression in the Dentate Gyrus after Acute Stress in vivo: Role of DNA Methylation and MicroRNA Activity. Neuroendocrinology. 2017;104(2):157-69.

Miller CA, Sweatt JD. Covalent modification of DNA regulates memory formation. Neuron. 2007 Mar;53(6):857-69.

Nikolova YS, Hariri AR. Can we observe epigenetic effects on human brain function? Trends Cogn Sci. 2015 Jul;19(7):366-73.

Oliveira AM, Hemstedt TJ, Bading H. Rescue of aging-associated decline in Dnmt3a2 expression restores cognitive abilities. Nat Neurosci. 2012 Jul;15(8):1111-3.

Palma-Gudiel H, Fañanás L. An integrative review of methylation at the serotonin transporter gene and its dialogue with environmental risk factors, psychopathology and 5-HTTLPR. Neurosci Biobehav Rev. 2017 Jan;72:190-209.

Park C, Rosenblat JD, Brietzke E, Pan Z, Lee Y, Cao B, et al. Stress, epigenetics and depression: A systematic review. Neurosci Biobehav Rev. 2019 Jul;102:139-52.

Pérez RF, Santamarina P, Tejedor JR, Urdinguio RG, Álvarez-Pitti J, Redon P, et al. Longitudinal genome-wide DNA methylation analysis uncovers persistent early-life DNA methylation changes. J Transl Med. 2019 Jan;17(1):15.

Perroud N, Salzmann A, Prada P, Nicastro R, Hoeppli ME, Furrer S, et al. Response to psychotherapy in borderline personality disorder and methylation status of the BDNF gene. Transl Psychiatry. 2013 Jan;3(1):e207.

Portela A, Esteller M. Epigenetic modifications and human disease. Nat Biotechnol. 2010 Oct; 28(10):1057-68.

Provenzi L, Guida E, Montirosso R. Preterm behavioral epigenetics: A systematic review. Neurosci Biobehav Rev. 2018 Jan;84:262-71. 
Rakyan VK, Down TA, Balding DJ, Beck S. Epigenome-wide association studies for common human diseases. Nat Rev Genet. 2011 Jul;12(8):529-41.

Roberts S, Keers R, Breen G, Coleman JR, Jöhren P, Kepa A, et al. DNA methylation of FKBP5 and response to exposure-based psychological therapy. Am J Med Genet B Neuropsychiatr Genet. 2019 Mar; 180(2):150-8.

Roberts S, Keers R, Lester KJ, Coleman JR, Breen $\mathrm{G}$, Arendt K, et al. HPA axis related genes and response to psychological therapies: genetics and epigenetics. Depress Anxiety. 2015 Dec; 32(12):861-70.

Roberts S, Lester KJ, Hudson JL, Rapee RM, Creswell C, Cooper PJ, et al. Serotonin transporter [corrected] methylation and response to cognitive behaviour therapy in children with anxiety disorders. Transl Psychiatry. 2014 Sep;4(9):e444.

Rodrigues GM Jr, Toffoli LV, Manfredo $\mathrm{MH}$ Francis-Oliveira J, Silva AS, Raquel HA, et al. Acute stress affects the global DNA methylation profile in rat brain: modulation by physical exercise. Behav Brain Res. 2015 Feb;279: 123-8.

Sapolsky RM, Romero LM, Munck AU. How do glucocorticoids influence stress responses? Integrating permissive, suppressive, stimulatory, and preparative actions. Endocr Rev. 2000 Feb;21(1):55-89.

Schroeder M, Hillemacher T, Bleich S, Frieling H. The epigenetic code in depression: implications for treatment. Clin Pharmacol Ther. 2012 Feb;91(2):310-4.

Schuebel K, Gitik M, Domschke K, Goldman D. Making Sense of Epigenetics. Int J Neuropsychopharmacol. 2016 Dec;19(11):1-10.

Segerstrom SC, Miller GE. Psychological stress and the human immune system: a meta-analytic study of 30 years of inquiry. Psychol Bull. 2004 Jul;130(4):601-30.

Selye H. Stress in health and disease. Boston/London. Butterworth-Heinemann; 2013.

Shabalin AA, Aberg KA, van den Oord EJ. Candidate gene methylation studies are at high risk of erroneous conclusions. Epigenomics. 2015; $7(1): 13-5$.

Siegmund KD, Connor CM, Campan M, Long TI, Weisenberger DJ, Biniszkiewicz D, et al. DNA methylation in the human cerebral cortex is dynamically regulated throughout the life span and involves differentiated neurons. PLoS One. 2007 Sep;2(9):e895.
Stoffel M, Aguilar-Raab C, Rahn S, Steinhilber B, Witt SH, Alexander N, et al. Effects of Mindfulness-Based Stress Prevention on Serotonin Transporter Gene Methylation. Psychother Psychosom. 2019a;88(5):317-9.

Stoffel M, Gardini E, Abbruzzese E, Moessner M, Ehlert U, Ditzen B. Association of FKBP5 intron 7 methylation with diurnal cortisol patterns in healthy subjects. Psychoneuroendocrinology. 2019b;107 Suppl:11.

Stoffel M, Gardini E, Ehlert U, Ditzen B. Alterations in DNA methylation of FKBP5 following a stress prevention program. Psychoneuroendocrinology. 2017;83 Suppl:45.

Sweatt JD. Experience-dependent epigenetic modifications in the central nervous system. Biol Psychiatry. 2009 Feb;65(3):191-7.

Szyf M, Tang YY, Hill KG, Musci R. The dynamic epigenome and its implications for behavioral interventions: a role for epigenetics to inform disorder prevention and health promotion. Transl Behav Med. 2016 Mar;6(1): 55-62.

Tang YY, Hölzel BK, Posner MI. The neuroscience of mindfulness meditation. Nat Rev Neurosci. 2015 Apr;16(4):213-25.

Techniker Krankenkasse. Entspann dich, Deutschland. TK-Stressstudie 2016. Hamburg, Techniker Krankenkasse, 2016. https:// www.tk.de/resource/blob/2026630/9154e4c7 1766c410dc859916aa798217/tk-stressstudie2016-data.pdf

Turecki G, Meaney MJ. Effects of the Social Environment and Stress on Glucocorticoid Receptor Gene Methylation: A Systematic Review. Biol Psychiatry. 2016 Jan;79(2):87-96.

Unternaehrer E, Luers P, Mill J, Dempster E, Meyer AH, Staehli S, et al. Dynamic changes in DNA methylation of stress-associated genes (OXTR, BDNF) after acute psychosocial stress. Transl Psychiatry. 2012 Aug; 2(8):e150.

Unternaehrer E, Meinlschmidt G. Psychosocial stress and DNA methylation. In: Spengler D, Binder E, editors. Epigenetics and Neuroendocrinology. Clinical Focus on Psychiatry. Cham: Springer; 2016. pp. 227-61.

Vaiserman AM. Epigenetic programming by early-life stress: evidence from human populations. Dev Dyn. 2015 Mar;244(3):254-65.

Van Daele T, Hermans D, Van Audenhove C, Van den Bergh O. Stress reduction through psychoeducation: a meta- analytic review. Health Educ Behav. 2012 Aug;39(4):474-85.

Varley KE, Gertz J, Bowling KM, Parker SL, Reddy TE, Pauli-Behn F, et al. Dynamic DNA methylation across diverse human cell lines and tissues. Genome Res. 2013 Mar;23(3): 555-67.
Varvogli L, Darviri C. Stress Management Techniques: evidence-based procedures that reduce stress and promote health. Health Sci J. 2011;5(2):74-89.

Weaver IC, Cervoni N, Champagne FA, D’Alessio AC, Sharma S, Seckl JR, et al. Epigenetic programming by maternal behavior. Nat Neurosci. 2004 Aug;7(8):847-54.

World Health Organization. Psychische Gesundheit: Herausforderungen annehmen, Lösungen schaffen: Bericht über die Ministerkonferenz der Europäischen Region der WHO. Kopenhagen, WHO-Regionalbüro für Europa, 2006. http://www.euro.who.int/_data/ assets/pdf_file/0009/96453/E87301G.pdf

Wray NR, Ripke S, Mattheisen M, Trzaskowski M, Byrne EM, Abdellaoui A, et al.; eQTLGen; 23andMe; Major Depressive Disorder Working Group of the Psychiatric Genomics Consortium. Genome-wide association analyses identify 44 risk variants and refine the genetic architecture of major depression. Nat Genet. 2018 May;50(5):668-81.

Wu Ct, Morris JR. Genes, genetics, and epigenetics: a correspondence. Science. 2001 Aug;293(5532):1103-5.

Yehuda R, Daskalakis NP, Desarnaud F, Makotkine I, Lehrner AL, Koch E, et al. Epigenetic Biomarkers as Predictors and Correlates of Symptom Improvement Following Psychotherapy in Combat Veterans with PTSD. Front Psychiatry. 2013 Sep;4:118.

Zannas AS, Binder EB. Gene-environment interactions at the FKBP5 locus: sensitive periods, mechanisms and pleiotropism. Genes Brain Behav. 2014 Jan;13(1):25-37.

Zannas AS, West AE. Epigenetics and the regulation of stress vulnerability and resilience. Neuroscience. 2014 Apr;264:157-70.

Zannas AS, Wiechmann T, Gassen NC, Binder EB. Gene-Stress-Epigenetic Regulation of FKBP5: Clinical and Translational Implications. Neuropsychopharmacology. 2016 Jan; 41(1):261-74.

Zhang B, Zhou Y, Lin N, Lowdon RF, Hong C, Nagarajan RP, et al. Functional DNA methylation differences between tissues, cell types, and across individuals discovered using the M\&M algorithm. Genome Res. 2013 Sep; 23(9):1522-40.

Ziegler C, Dannlowski U, Bräuer D, Stevens S, Laeger I, Wittmann H, et al. Oxytocin receptor gene methylation: converging multilevel evidence for a role in social anxiety. Neuropsychopharmacology. 2015 May;40(6):152838 . 